Біловодська Олена, доктор економічних наук, професор, Київський національний університет технологій та дизайну, кафедра маркетингу та комунікаційного дизайну,

м. Київ; ORCID ID: 0000-0003-3707-0734 e-mail: alenabel79@gmail.com

https://doi.org/10.29038/2786-4618-2021-01-175-183

\title{
КВАЛІМЕТРИЧНИЙ ПІДХІД ОЦІНЮВАННЯ СТРАТЕГІЧНОЇ ДІЯЛЬНОСТІ УПРАВЛІННЯ ДИСТРИБУЦІЕЮ ІННОВАЦІЙНИХ ПРОДУКТІВ У МАРКЕТИНГОВІЙ ЛОГІСТИЦІ ${ }^{1}$
}

Стратегічна діяльність забезпечення інноваційних процесів, поєднуючи розроблення, безпосереднє виробництво та дистрибуцію нової продукції, спрямована насамперед на вдосконалення продуктів компанії, взаємодію зі споживачами, пошук та розширення нових ринків збуту тощо. 3 цих позицій оцінювання стратегії управління дистрибуції, яка забезпечує задоволення потреб і запитів споживачів, $є$ важливим етапом підвищення ефективності компанії. У статті виконано оцінювання стратегії управління розподілом інноваційної продукції в логістиці хімічної компанії з позицій споживачів на основі кваліметричного підходу та наведено комплекс рекомендацій щодо ії вдосконалення, що є основою для методології вибору найбільш об’єктивної стратегічної альтернативи в хімічній компанії.

Ключові слова: дистрибуція, стратегічна діяльність, стратегія, хімічна промисловість, компанія, споживач, інноваційна продукція, маркетингова логістика.

Беловодская Елена, доктор экономических наук, профессор, Киевский национальный университет технологий и дизайна, кафедра маркетинга и коммуникационного дизайна,

г. Киев

\section{КВАЛИМЕТРИЧЕСКИЙ ПОДХОД К ОЦЕНКЕ СТРАТЕГИЧЕСКОЙ ДЕЯТЕЛЬНОСТИ УПРАВЛЕНИЯ ДИСТРИБУЦИЕЙ ИННОВАЦИОННЫХ ПРОДУКТОВ В МАРКЕТИНГОВОЙ ЛОГИСТИКЕ}

\begin{abstract}
Стратегическая деятельность обеспечения инновационных процессов, сочетая разработку, непосредственное производство и дистрибуцию новой продукции, направлена прежде всего на совершенствование продуктов компании, взаимодействие с потребителями, поиск и расширение новых рынков сбыта и тому подобное. С этих позиций оценка стратегии управления дистрибуцией, которая обеспечивает удовлетворение потребностей и запросов потребителей, является важным этапом повышения эффективности компании. В статье выполнено оценивание стратегии управления дистрибуцией инновационной продукции в маркетинговой логистике химической компании с позиций потребителей на основе квалиметричного подхода, приведен комплекс рекомендаций по ее усовершенствованию, что является основой для методологии выбора наиболее объективной стратегической альтернативы химической компании.
\end{abstract}

Ключевые слова: дистрибуция, стратегическая деятельность, стратегия, химическая промышленность, компания, потребитель, инновационная продукция, маркетинговая логистика.

Bilovodska Olena,

Doctor of Science (Economics), Professor, Kyiv National University of Technology and Design,

1 Публікація містить результати досліджень, проведених за ініціативною науково-дослідною роботою «Маркетингові та логістичні механізми управління інноваційним розвитком суб'єктів господарювання» (0120U104616). 


\title{
QUALIMETRIC APPROACH TO EVALUATING THE DISTRIBUTION MANAGEMENT STRATEGY OF INNOVATIVE PRODUCTS IN MARKETING LOGISTICS
}

\begin{abstract}
Strategic activities to ensure innovation processes, combining the development, direct production and distribution of new products, aimed primarily at improving the company's products, interaction with consumers, search and expansion of new markets ets. From these perspectives, evaluating a distribution management strategy that meets the needs and demands of consumers is an important step in improving a company's efficiency. The article evaluates the strategy of managing the distribution of innovative products in the marketing logistics of a chemical company from the standpoint of consumers on the basis of a qualimetric approach. According to the results of the evaluation, it was found that the strategy needs to be improved by increasing the rate of profit compared to the rate of price growth. There is also a set of recommendations for improving the strategy of managing the distribution of innovative products in marketing logistics in accordance with the prospects of the consumer, which is the basis for the methodology of choosing the most objective strategic alternative in a chemical company.

The object of research is the process of evaluating the strategic activities of the distribution management by innovative products. The information base consists of information-analytical reports of the chemical industry company, scientific works of domestic and foreign scientists in the field of marketing logistics, innovation marketing and innovation management, data collected by the author of the chemical industry. In the study, the author used a qualimetric approach, the Spearman rank correlation coefficient. The obtained results can be further used for research and comparison of other industrial enterprises in different industries.
\end{abstract}

Keywords: distribution, strategic activity, strategy, chemical industry, company, consumer, innovative products, marketing logistics.

Постанова проблеми та їі значення. Сьогодні компанії хімічної промисловості стикаються 3 труднощами у підтримці своєї конкурентоспроможності. Це пояснюється впливом глобальних мегатрендів у різних галузях, включаючи хімічну. Тому дуже важливо мати чітко розроблену стратегію та систему управління, здатну реагувати на внутрішні та зовнішні зміни. Більшість існуючих методів оцінювання стратегії $\epsilon$ загальними і грунтуються лише на внутрішніх бізнеспоказниках, вони не відображають ефективність ринку, яка базується, перш за все, на споживацьких оцінках. Більше того стратегія сучасної компанії повинна відповідати інтересам споживачів i особливо це стосується виробництва та розповсюдження інноваційної продукції.

Аналіз останніх досліджень та публікацій. Об'єктом дослідження є процеси оцінювання стратегічної діяльності управління дистрибуцією інноваційних продуктів. Так, багато дослідників підкреслюють, що стратегія дистрибуції чи збуту займає ключове місце в порівнянні зі стратегіями комунікацій, товару та ціноутворення. Таким чином, Аміко С. [1] визначає «стратегію продажів» як план бізнесу щодо того, як займатися продажем товарів та послуг та збільшенням прибутку. Стратегії продажів, як правило, розробляються адміністрацією компанії разом із менеджерами 3 продажу, маркетингу та реклами.

Золтерс, Сінха та Лоример [2] визначають «стратегію збуту» як «план, за допомогою якого організація виконує свої функції збуту, цілями якого є продаж продукції чи послуг або те й інше, а також збільшення прибутку за рахунок органічного зростання. Важливою частиною стратегії продажів є визначення клієнтської бази та розуміння доданої вартості, яку ваша організація може принести вашим клієнтам».

HubSpot Inc. [3] зазначає, що «стратегія продажів - це підхід до продажу, що дозволяє торговому представництву розміщувати компанію та іiі товар для націлювання на споживачів значущим, диференційованим способом».

Сторбака К., Райалс Л., Девіс І. та Ненонен С. [4] визначають, що «стратегії продажів мають значення для процесу продажів та інтерфейсу продажів не тільки 3 клієнтами, але й усередині організації».

Таким чином, виходячи з проведеного дослідження концепцій, можна зазначити, що «стратегія дистрибуції / збуту» є частиною загальної стратегії компанії, основною метою якої $є$ не лише 
доведення продукції до споживачів, а й врахування власних інтересів.

Багато вчених вивчають особливості інновацій у маркетингу та інших сферах бізнесу. Так, Ілляшенко С. [5] розробив «методологічний підхід до управління інноваційною діяльністю підприємств на основі принципів маркетингу інновацій. Практична реалізація дає змогу цілеспрямованому управлінню інновацією та впровадженню ринково-орієнтованої стратегії інноваційного розвитку для національних виробників».

Бабенко В. [6], [7] досліджувала «процес формалізації управління технологічними інноваціями». Цей автор та Романенков Ю., Якимова Л. та Накіско А. [8] розробили «детальну модель багатокритеріальної оптимізації управління інноваційним процесом на підприємстві в умовах ризиків, яка повністю описує динаміку досліджуваного процесу».

Перерва П., Беспрозванних О., Тютлікова В., Ковалова В., Кудіна О. та Дорохов О. [9] вдосконалили «методику відбору інноваційних проектів за рейтинговою оцінкою їх економічної ефективності». Вони запропонували «провести інтегровану оцінку, яка передбачає ранжування проектів за рівнем окремих показників економічної ефективності».

Досить грунтовне дослідження 3 оцінки розподілу в стратегічному управлінні знайшло відображення в працях зарубіжних та вітчизняних вчених. Зокрема, Хуанг С., Цзян Х. [10] запропонував «мультимодальну оцінку алгоритму розподілу (EDA) на основі кооперативної кластеризації, яка може не тільки ефективно досліджувати та експлуатувати перспективні регіони в просторі пошуку, але й отримувати глобальний оптимум, що перевершує типовий мультимодальна EDA».

Ванг Л., Фан Х., Гонг Т. [11] запропонували «метод вирішення, які види оптимізації стратегій закупівель слід застосовувати для роздрібних торговців у різних сферах, позитивні стратегії або консервативні стратегії».

Курбацька Л., Ільченко Т. та Кадирус I. [12] запропонували “комплекс маркетингових стратегій розподільчої діяльності в сільськогосподарському підприємстві”.

Поліщук I. [13] запропонував «виміряти ефективність маркетингової (або розподільчої) стратегії, використовуючи «маркетингову віддачу як відношення чистого доходу до витрат, понесених на маркетингову діяльність». Також цей автор запропонував ефективність реалізації підприємством маркетингової стратегії для вимірювання сукупності таких показників: дебіторська заборгованість за товари, роботи, послуги на кінець року; чистий дохід від реалізації продукції; загальний прибуток; тривалість обороту дебіторської заборгованості за товари; маркетингові витрати; частка маркетингових витрат у витратах підприємства та інші.

Персауд Н., Вудхауз-Джексон М., Скривен М. [14] аналізують «дві моделі для оцінки стратегічної діяльності: контрольний перелік ключових оцінок (КEC) та SMM, виділяють їх порівняльні характеристики».

Ривера Б., Бекер П., Папа Ф., Олсина Л. [15] розробляють «цілісний якісний багаторівневий та багатоцільовий підхід до оцінки. Це пов'язує багаторівневі цілі, проекти та інтегровані стратегії».

Нортон С., Мілат А., Едвардс Б., Гіффін М. [16] визначають оцінені стратегії, що використовуються «організаціями та розробниками програм для створення спроможності оцінювати програми своєї робочої сили та для опису факторів успіху та отриманих уроків».

Рінтанен Дж. [17] досліджує «різні стратегії оцінки проблем планування, що представляються як проблеми задоволення обмежень або задоволеності, і представляє стратегії оцінки, засновані на паралельній або перемежованій оцінці кількох формул, і показує, що при багатьох проблемах це призводить до суттєвого покращення часу роботи, іноді на кілька порядків величини».

Кара Н. [18] присвячує проблемам «оцінки впливу зовнішнього середовища на діяльність підприємства».

Савицька Н., Чміль Х., Грабильникова О., Пушкіна О., Вакуліч М. [19] досліджують «фактори сприйняття стилів управління 3 метою забезпечення безпеки функціонування підприємства в контексті трансформації соціальної системи при реалізації стратегій, спрямованих на ії розвиток».

Серединська В., Загородня О. [20] «необхідність використання інноваційних інструментів управління та шляхів їх інтеграції для розвитку стратегічного напрямку компанії, систематизації методів стратегічного управління інструментами та їх реалізації».

Шоріков А., Бабенко В. [21] пропонують «використовувати детермінований підхід для 
моделювання та вирішення початкових задач у вигляді динамічної задачі управління мінімаксною програмою (оптимізація гарантованого результату) ІПП на заданий момент часу 3 урахуванням ризиків».

Однак проблематика оцінювання стратегічної діяльності управління дистрибуцією інноваційних продуктів у маркетинговій логістиці залишається невирішеною.

Мета і завдання статті. Метою статті $\epsilon$ оцінювання стратегічної діяльності управління дистрибуцією відповідно до особливостей інноваційної діяльності підприємства на основі кваліметричного підходу. Завдання даного дослідження полягають у: 1) порівняльному аналізі параметрів інноваційної продукції компанії хімічної галузі; 2) розрахунку інтегрованих показників оцінюваних параметрів; 3) оцінюванні відповідності між нормативною та фактичною структурою показників за коефіцієнтом Спірмена; 4) формуванні комплексу рекомендацій щодо вдосконалення стратегії управління дистрибуцією інноваційної продукції в маркетинговій логістиці.

Виклад основного матеріалу та обгрунтування отриманих результатів дослідження. Науковотехнічне оновлення економіки є пріоритетним напрямком розвитку будь-якої держави, включаючи Україну. Інновації $є$ ключовим фактором успіху бізнесу та одним із мегатенденцій хімічної промисловості.

Виходячи 3 цього, інноваційний розвиток хімічної промисловості вимагає формування сприятливих економічних, правових та організаційних умов для функціонування суб'єктів господарювання на внутрішньому та міжнародному ринках. Це вимагає впровадження технічного законодавства ЄС щодо розвитку хімічної промисловості, регулювання конкурентних відносин між країнами, виробництва мінеральних добрив та хімічної продукції з вітчизняної сировини. Таким чином, ефективна стратегія повинна узгоджуватися 3 принципами управління інноваціями (реалізація цінності, використання інсайтів, орієнтовані на майбутнє лідери, стратегічне спрямування, системний підхід, адаптивні структури, інноваційна культура та управління невизначеністю). Ці принципи повинні стати основою для концепції оцінки бізнес-стратегії інноваційного підприємства.

Підсумовуючи, на жаль, проблеми оцінки стратегії управління дистрибуцією в процесі випуску інноваційних продуктів з урахуванням маркетингових орієнтирів, недостатньо досліджені. Хімічна промисловість також не є глибоко дослідженою. Однак це має мати вирішальне значення для економічного зростання в сучасних реаліях. Тож метою статті $є$ оцінка стратегій управління розподілом інноваційної продукції на хімічних підприємствах відповідно до перспектив споживача.

Згідно $з$ попередніми дослідженнями [22], [23], стратегію доцільно оцінювати 3 точки зору споживача, використовуючи два фактори: ціни на товари компанії та значення показників, що враховують вигоди споживачів від використання товарів. Цей підхід може стати основою для оцінювання стратегічної діяльності управління дистрибуцією інноваційних продуктів.

Тож об'єктом дослідження ми обрали ПАТ «Сумихімпром». Ця компанія є відомим підприємством хімічної промисловості в Україні, що виготовляє мінеральні добрива, коагулянти та добавки до цементу, кислоту, діоксид титану, пігменти та інші види хімічної продукції. Асортимент продукції, що виробляється ПАТ «Сумихімпром», є досить широким, однак станом на початок 2020 p. 63,6\% продукції, що випускається підприємством, є діоксид титану. Крім того, 3 відходів титанового виробництва виготовляється сульфат заліза, що може використовуватися як кормова добавка. Варто зазначити, що на території України ПАТ «Сумихімпром» є єдиним виробником діоксиду титану (продукція підприємства «Крымский титан» відсутня на ринку України у зв’язку 3 анексією АРК) [24]. Ці види продукції практично не залежать від сезонних факторів та мають високий експортний потенціал.

Дана компанія використовує стратегію реалізації конкурентної переваги для управління процесом дистрибуції інноваційної продукції.

Значення показників, що враховують переваги споживачів від використання діоксиду титану та сульфату заліза, розраховуємо на основі параметрів оцінки, характерних для цих видів інноваційних продуктів. У даній роботі ми розглядаємо 6 брендів діоксиду титану, що випускаються компанією: SumTITAN R-204, SumTitan R-206 (стандартні марки), SumTitan R-2041, SumTitan R-2061, SumTitan R-2071, SumTitan R-208 (табл. 1) та 4 марки сульфату заліза: марка A, марка B, марка C, марка F (табл. 2). 
Характеристика діоксиду титану

\begin{tabular}{|l|c|c|c|c|c|c|c|}
\hline \multicolumn{1}{|c|}{ Продукт } & $\begin{array}{c}\text { Діоксид } \\
\text { титану, } \\
\text { мас.частка, } \\
\text { \% }\end{array}$ & $\begin{array}{c}\text { Рутильна } \\
\text { форма, } \\
\text { масова } \\
\text { частка, \% }\end{array}$ & $\begin{array}{c}\text { Розбілю- } \\
\text { юча } \\
\text { здатність, } \\
\text { ум. од. }\end{array}$ & $\begin{array}{c}\text { Диспер- } \\
\text { гованість, } \\
\text { мкм, } \\
\text { макс.1 }\end{array}$ & $\begin{array}{c}\text { Покрив- } \\
\text { ність, } \\
\text { г/м2, } \\
\text { макс. }\end{array}$ & $\begin{array}{c}\text { Гарантійний } \\
\text { термін } \\
\text { зберігання, } \\
\text { років }\end{array}$ & $\begin{array}{c}\text { Паспорт } \\
\text { безпеч- } \\
\text { ності }\end{array}$ \\
\hline $\begin{array}{l}\text { SumTitan R-204, } \\
\text { SumTitan R-206 } \\
\text { (стандарт) }\end{array}$ & 94 & 97 & 2000 & 45 & 25 & 1 & 1 \\
\hline SumTitan R-2041 & 94 & 97 & 2050 & 40 & 24 & 1 & 1 \\
\hline SumTitan R-2061 & 94 & 97 & 2000 & 40 & 24 & 1 & 1 \\
\hline SumTitan R-2071 & 95 & 98 & 2100 & 35 & 24 & 1 & 1 \\
\hline SumTitan R-208 & 93 & 98 & 2100 & 35 & 24 & 1 & 1 \\
\hline Optimal value & $95 \max$ & $98 \max$ & $2100 \max$ & 35 min & 25 max & 1 max & 1 max \\
\hline Weighting & 0,16 & 0,16 & 0,16 & 0,16 & 0,16 & 0,1 & 0,1 \\
\hline
\end{tabular}

* - паспорт безпечності: 1 - паспорт $\epsilon, 0$ - паспорт відсутній.

Джерело: власні розрахунки (на основі [24])

Для розрахунку інтегрованих показників визначено вагові характеристики одиничних показників. Оскільки показники $є$ рівноважливими, їх зважувані оцінки $є$ майже однаковими. Розрахуємо інтегральні значення на основі підходу, викладеного у роботах [22], [23]:

$$
\begin{aligned}
& P_{\text {standard }}=0,16 \cdot \frac{94}{95}+0,16 \cdot \frac{97}{98}+0,16 \cdot \frac{2000}{2100}+0,16 \cdot \frac{35}{45}+0,16 \cdot \frac{25}{25}+0,1 \cdot \frac{1}{1}+0,1 \cdot \frac{1}{1}=0.954 \text {. } \\
& P_{\text {SumTitan R-2041 }}=0,16 \cdot \frac{94}{95}+0,16 \cdot \frac{97}{98}+0,16 \cdot \frac{2050}{2100}+0,16 \cdot \frac{35}{40}+0,16 \cdot \frac{24}{25}+0,1 \cdot \frac{1}{1}+0,1 \cdot \frac{1}{1}=0,966 \text {; } \\
& P_{\text {SumTitan R-2061 }}=0,16 \cdot \frac{94}{95}+0,16 \cdot \frac{97}{98}+0,16 \cdot \frac{2000}{2100}+0,16 \cdot \frac{35}{40}+0,16 \cdot \frac{24}{25}+0,1 \cdot \frac{1}{1}+0,1 \cdot \frac{1}{1}=0,963 \text {; } \\
& P_{\text {SumTitan R-2071 }}=0,16 \cdot \frac{95}{95}+0,16 \cdot \frac{98}{98}+0,16 \cdot \frac{2100}{2100}+0,16 \cdot \frac{35}{35}+0,16 \cdot \frac{24}{25}+0,1 \cdot \frac{1}{1}+0,1 \cdot \frac{1}{1}=0,994 ; \\
& P_{\text {SumTitan R-208 }}=0,16 \cdot \frac{93}{95}+0,16 \cdot \frac{98}{98}+0,16 \cdot \frac{2100}{2100}+0,16 \cdot \frac{35}{35}+0,16 \cdot \frac{24}{25}+0,1 \cdot \frac{1}{1}+0,1 \cdot \frac{1}{1}=0,990 \text {. }
\end{aligned}
$$

\begin{tabular}{|c|c|c|c|c|c|c|c|c|c|c|c|}
\hline Продукт & 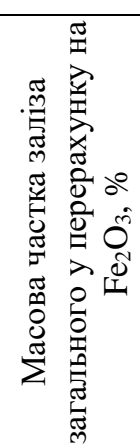 & 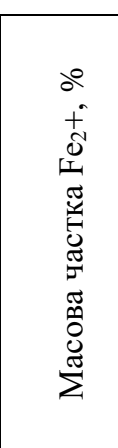 & 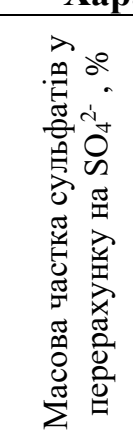 & 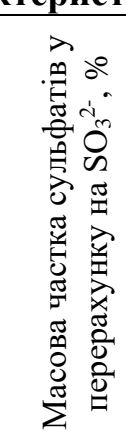 & 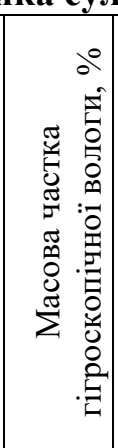 & 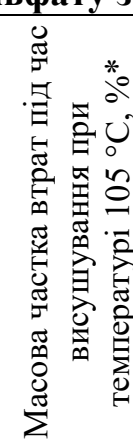 & 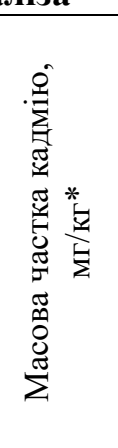 & 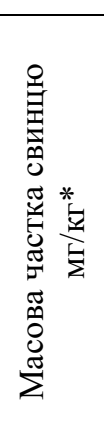 & 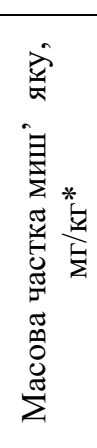 & 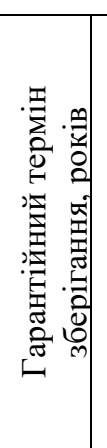 & 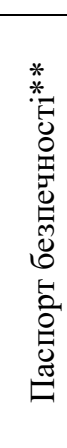 \\
\hline Марка A & 35 & 25 & 42 & 36 & 5 & - & - & - & - & 1 & 1 \\
\hline Марка В & 18 & 13 & 35 & 30 & 6 & - & - & - & - & 1 & 1 \\
\hline Марка C & 39 & 28 & 47 & 39 & 5 & - & - & - & - & 1 & 1 \\
\hline Марка F & 42 & 30 & 50 & 42 & 4 & 6,1 & 10 & 100 & 30 & 1 & 1 \\
\hline $\begin{array}{l}\text { Оптималь-не } \\
\text { значення }\end{array}$ & $42 \max$ & $30 \max$ & $50 \max$ & $42 \max$ & $4 \min$ & $6,1 \mathrm{~min}$ & $10 \mathrm{~min}$ & $\begin{array}{l}100 \\
\min \end{array}$ & $\begin{array}{c}30 \\
\text { min }\end{array}$ & $\begin{array}{c}1 \\
\max \end{array}$ & $\begin{array}{c}1 \\
\max \end{array}$ \\
\hline Вагомість & 0,1 & 0,1 & 0,1 & 0,1 & 0,1 & 0,075 & 0,075 & 0,075 & 0,075 & 0,1 & 0,1 \\
\hline
\end{tabular}

Таблиця 2

\section{Характеристика сульфату заліза}

* - нормування показника: - показник не нормується;

** - паспорт безпечності: 1 - паспорт $\epsilon, 0$ - паспорт відсутній.

Джерело: власні розрахунки (на основі [24]) 


$$
\begin{aligned}
& \mathrm{P}_{\text {Mapks } A}=0,1 \cdot \frac{35}{42}+0,1 \cdot \frac{25}{30}+0,1 \cdot \frac{42}{50}+0,1 \cdot \frac{36}{42}+0,1 \cdot \frac{4}{5}+0,1 \cdot \frac{1}{1}+0,1 \cdot \frac{1}{1}=0,616 \\
& \mathrm{P}_{\text {Mapka B }}=0,1 \cdot \frac{18}{42}+0,1 \cdot \frac{13}{30}+0,1 \cdot \frac{35}{50}+0,1 \cdot \frac{30}{42}+0,1 \cdot \frac{4}{6}+0,1 \cdot \frac{1}{1}+0,1 \cdot \frac{1}{1}=0,494 \\
& \mathrm{P}_{\text {Mapks C }}=0,1 \cdot \frac{39}{42}+0,1 \cdot \frac{28}{30}+0,1 \cdot \frac{47}{50}+0,1 \cdot \frac{39}{42}+0,1 \cdot \frac{4}{5}+0,1 \cdot \frac{1}{1}+0,1 \cdot \frac{1}{1}=0,653 \\
& \mathrm{P}_{\text {Mapks F F }}=0,1 \cdot \frac{42}{42}+0,1 \cdot \frac{30}{30}+0,1 \cdot \frac{50}{50}+0,1 \cdot \frac{42}{42}+0,1 \cdot \frac{4}{4}+0,075 \cdot \frac{6,1}{6,1}+0,075 \cdot \frac{10}{10}+0,075 \cdot \frac{100}{100}+ \\
& +0,075 \cdot \frac{30}{30}+0,1 \cdot \frac{1}{1}+0,1 \cdot \frac{1}{1}=1 .
\end{aligned}
$$

Виходячи з вищенаведеної інформації, оцінимо відповідність між нормативною та фактичною

\begin{tabular}{|c|c|c|c|c|c|c|}
\hline Нормативний показник, $X_{i}$ & 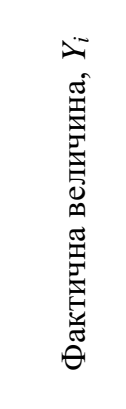 & 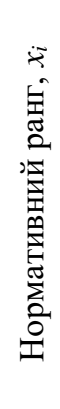 & 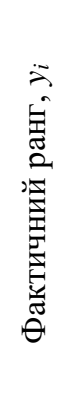 & 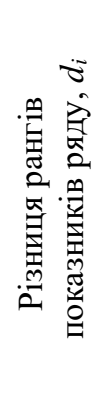 & 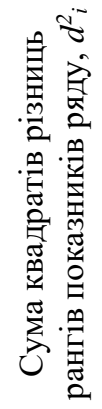 & 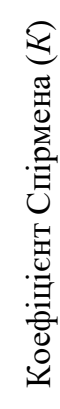 \\
\hline \multicolumn{7}{|c|}{2012} \\
\hline Темп зростання цін на продукцію & $101,6 \%$ & 1 & 2 & -1 & 1 & \multirow{2}{*}{-1} \\
\hline Темп зростання значення показника вигод & $100 \%$ & 2 & 1 & 1 & 1 & \\
\hline \multicolumn{7}{|c|}{2013} \\
\hline Темп зростання цін на продукцію & $96,6 \%$ & 1 & 1 & 0 & 0 & \multirow{2}{*}{1} \\
\hline Темп зростання значення показника вигод & $101,4 \%$ & 2 & 2 & 0 & 0 & \\
\hline \multicolumn{7}{|c|}{2014} \\
\hline Темп зростання цін на продукцію & $127,8 \%$ & 1 & 2 & -1 & 1 & \multirow{2}{*}{-1} \\
\hline Темп зростання значення показника вигод & $99,6 \%$ & 2 & 1 & 1 & 1 & \\
\hline \multicolumn{7}{|c|}{2015} \\
\hline Темп зростання цін на продукцію & $148,9 \%$ & 1 & 2 & -1 & 1 & \multirow{2}{*}{-1} \\
\hline Темп зростання значення показника вигод & $103,2 \%$ & 2 & 1 & 1 & 1 & \\
\hline \multicolumn{7}{|c|}{2016} \\
\hline Темп зростання цін на продукцію & $101,3 \%$ & 1 & 2 & -1 & 1 & \multirow{2}{*}{-1} \\
\hline Темп зростання значення показника вигод & $99,7 \%$ & 2 & 1 & 1 & 1 & \\
\hline \multicolumn{7}{|c|}{2017} \\
\hline Темп зростання цін на продукцію & $98,6 \%$ & 1 & 1 & 0 & 0 & \multirow{2}{*}{1} \\
\hline Темп зростання значення показника вигод & $101,5 \%$ & 2 & 2 & 0 & 0 & \\
\hline \multicolumn{7}{|l|}{$e^{2}$} \\
\hline Темп зростання цін на продукцію & $102,3 \%$ & 1 & 2 & -1 & 1 & \multirow{2}{*}{-1} \\
\hline Темп зростання значення показника вигод & $98,6 \%$ & 2 & 1 & 1 & 1 & \\
\hline \multicolumn{7}{|c|}{2019} \\
\hline Темп зростання цін на продукцію & $104,6 \%$ & 1 & 2 & -1 & 1 & \multirow{2}{*}{-1} \\
\hline Темп зростання значення показника вигод & $99,6 \%$ & 2 & 1 & 1 & 1 & \\
\hline
\end{tabular}
структурою показників за коефіцієнтом кореляції рангу Спірмена (К) (табл. 3).

Таблиия 3

Взаємозв'язок нормативного та фактичного ряду показників з точки зору споживача протягом 2012-2019 років для ПАТ «Сумихімпром»

Отже, протягом аналізованого періоду щодо значень коефіцієнта Спірмена (табл. 2) для 
споживачів даний показник, за винятком 2013 і 2017 pp., дорівнює -1, тобто спостерігається негативне співвідношення, оскільки показники розміщені у зворотному порядку, що свідчить про негативну кореляцію. Зростання коефіцієнта Спірмена до +1 у 2013 та 2017 рр. спричинено тим, що компанія внесла зміни до стандартних марок діоксиду титану, що призвело до збільшення переваг споживачів, а подальші зміни марок діоксиду титану були менш значними.

Однак той факт, що коефіцієнт Спірмена отримав екстремальне значення -1 протягом 2014-2016 років включно, не означає, що діяльність компанії орієнтована на зниження результативності. Перш за все, варто зазначити, що у 2014 та 2015 роках відбулося значне зростання цін на продукцію, викликане нестабільністю внутрішньої ситуації в країні. Відповідно, темп зростання показника вигоди був меншим, ніж темп зростання цін. Хоча компанія постійно вдосконалює свою продукцію, включаючи випуск нових марок діоксиду титану та сульфату заліза, їх характеристики суттєво не відрізняються, що $\epsilon$ причиною повільного зростання показника вигоди за роками. Причиною цього $\epsilon$ те, що діоксид титану є продуктом з унікальними властивостями - головним білим барвником у світі. Ось чому внесення суттєвих змін у цей продукт є досить складним процесом, який може призвести до негативних наслідків, наприклад, збільшення розчинності діоксиду титану або підвищення його здатності взаємодіяти з кислотами та лугами, що є небажаним.

Висновки та перспективи подальших досліджень. Згідно з вищесказаним, процес реалізації стратегії ускладнюється поточними обставинами і вимагає підтримки та контролю 3 боку керівництва. Крім того, для вдосконалення стратегії управління дистрибуцією також необхідно стежити за основними міжнародними тенденціями в хімічній промисловості та враховувати динаміку основних показників щодо хімічної промисловості на світовому ринку. Відповідно, можна зазначити, що компанії потрібно переглянути діючу стратегію управління дистрибуцією, враховуючи фактичний стан показників. Отже, можна запропонувати використовувати стратегію інновацій у розподілі. Крім того. незважаючи на зростаючу важливість цієї галузі у світовому масштабі та наявний місцевий потенціал, українська хімічна промисловість потребує додаткових капітальних вкладень та подальшого розвитку. Перспективи подальших досліджень у цій галузі повинні бути спрямовані на дослідження та порівняння інших промислових підприємств різних галузей.

\section{Джерела та література}

1. Amico S. Definition of Sales Strategy. URL: https://smallbusiness.chron.com/definition-sales-strategy2213.html (дата звернення 07.03.2021).

2. Zolters S. Analysing and Improving the Sales Strategy and Process Case: Robert Bosch Oy. URL : https://www.theseus.fi/bitstream/handle/10024/129374/Kuosa_Samuel.pdf?sequence=1 (дата звернення 05.03.2021).

3. Official website of HubSpot, Inc. URL : https://www.hubspot.com/sales/sales-strategy (дата звернення 25.03.2021).

4. Storbacka K., Ryals L., Davies I., Nenonen S. The changing role of sales: viewing sales as a strategic, crossfunctional process. European Journal of Marketing. 2009. Vol. 43. No. 7/8. P. 890-906. URL : https://core.ac.uk/download/pdf/140054.pdf (дата звернення 02.03.2021).

5. Ілляшенко С.М. Стратегічне управління інноваційною діяльністю підприємства на основі маркетингу інновацій. Актуальні проблеми економіки. 2010. № 12. С. 111-119.

6. Бабенко В.А. Формирование экономико-математической модели динамики процесса управления инновационными технологиями на предприятиях АПК. Актуальні проблеми економіки. 2013. № 1 (139). С. 182-186.

7. Babenko V. Formalization of the Model of Management of the Technological Innovations. CEUR Workshop Proceedings. 2019. № 2393. P. 595-602. URL : http://ceur-ws.org/Vol-2393/paper_431.pdf (дата звернення 02.03.2021).

8. Babenko V., Romanenkov Yu., Yakymova L., Nakisko A., Development of the model of minimax adaptive management of innovative processes at an enterprise with consideration of risks. Eastern-European Journal of Enterprise Technologies. 2017. № 4(89). Вип. 5. Р. 49-56. URL : https://doi.org/10.15587/1729-4061.2017.112076 (дата звернення 04.03.2021).

9. Pererva P., Besprozvannykh O., Tiutlikova V., Kovalova V., Kudina O., Dorokhov O. Improvement of the Method for Selecting Innovation Projects on the Platform of Innovative Supermarket. TEM Journal. 2019. № 8 (2). P. 454-461. URL : https://doi.org/10.18421/TEM82-19 (дата звернення 06.03.2021).

10. Huang S., Jiang H. Multimodal estimation of distribution algorithm based on cooperative clustering strategy. Chinese Control And Decision Conference (CCDC). 2018, 5297-5302. URL : https://ieeexplore.ieee.org/document/8408052 (дата звернення 03.03.2021). 
11. Wang L., Fan H., Gong T. The Consumer Demand Estimating and Purchasing Strategies Optimizing of FMCG Retailers Based on Geographic Methods. Sustainability. $2018 . \quad$ № $10 . \quad$ URL : https://doi.org/10.3390/su10020466 (дата звернення 03.03.2021).

12. Курбацька Л.М., Ільченко Т.В., Кадирус І.Г. Теоретичні аспекти маркетингового забезпечення ефективної розподільчо-збутової політики аграрного підприємства. Науковий вісник Херсонського держсавного

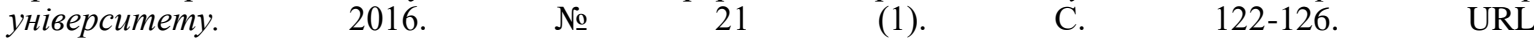
https://dspace.dsau.dp.ua/jspui/bitstream/123456789/240/1/\%d0\%a1\%d1\%82\%d0\%b0\%d1\%82\%d1\%82\%d1\%8f \%d 0\%9a\%d1\%83\%d1\%80\%d0\%b1\%d0\%b0\%d1\%86\%d1\%8c\%d0\%ba\%d0\%b0\%2c\%20\%d0\%86\%d0\%bb\%d1\%8c\%d1 $\% 87 \%$ d0\%b5\%d0\%bd\%d0\%ba\%d0\%be\%2c\%20\%d0\%9a\%d0\%b0\%d0\%b4\%d0\%b8\%d1\%80\%d1\%83\%d1\%81.pdf (дата звернення 04.03.2021).

13. Поліщук I.P. Оцінка ефективності маркетингової стратегії підприємства. Проблеми теорії та методологї бухгалтерського обліку, контролю та аналізу. 2015. № 3 (33). C. 259-271. URL : http://eztuir.ztu.edu.ua/bitstream/handle/123456789/2582/24.pdf?sequence=1\&isAllowed=y (дата звернення 05.03.2021).

14. Persaud N., Woodhouse-Jackson M., Scriven M. Enhancing the Strategic Management Process Through the Use of Professional Evaluation Methods and the Logic of Evaluation. Journal of MultiDisciplinary Evaluation. 2016.

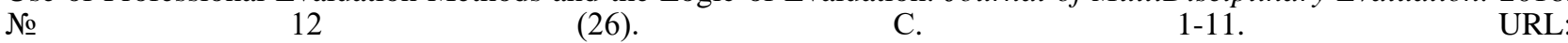
https://www.academia.edu/23582472/Enhancing_the_Strategic_Management_Process_Through_the_Use_of_Professio nal_Evaluation_Methods_and_the_Logic_of_Evaluation (дата звернення 03.03.2021).

15. Rivera B., Becker P., Papa F., Olsina L. A Holistic Quality Evaluation, Selection and Improvement Approach driven by Multilevel Goals and Strategies. CLEI Electronic Journal. 2016. № 19 (3). URL: http://www.scielo.edu.uy/scielo.php?script=sci_arttext\&pid=S0717-50002016000300054 (дата звернення 02.03.2021).

16. Norton S., Milat A., Edwards B., Giffin, M. Narrative review of strategies by organizations for building evaluation capacity. Evaluation and Program Planning. 2016. № 58 . C. 1-19. URL: https://www.sciencedirect.com/science/article/pii/S0149718915300616 (дата звернення 02.03.2021).

17. Rintanen J. Evaluation Strategies for Planning as Satisfiability. URL: https://users.aalto.fi/ rintanj1/jussi/papers/Rintanen04ecai.pdf (дата звернення 04.03.2021)

18. Кара Н.I. Види стратегій та оцінювання впливу факторів зовнішнього середовища на діяльність підприємства. URL:http://ena.lp.edu.ua/bitstream/ntb/34889/1/16 97-102.pdf (дата звернення 05. 03.2021).

19. Savytska N., Chmil H., Hrabylnikova O., Pushkina O., Vakulich, M. Behavioral models for ensuring the security of functioning and organizational sustainability of the enterprise. Journal of Security and Sustainability. 2019. № 9(1). P. 63-76. DOI: 10.9770/jssi.2019.9.1(6).

20. Серединська В., Загородна О.М. Напрями вдосконалення стратегічного управління на підприємстві. Економіка і суспільство. 2016. № 3. P. 276-285. URL: http://www.economyandsociety.in.ua/journal/3_ukr/49.pdf (дата звернення 06.03.2021).

21. Шориков А.Ф., Бабенко В.А. Оптимизация гарантированного результата в динамической модели управления инновационным процессом на предприятии. Экономика региона. 2014. №1. C. 196-202. DOI: 10.17059/2014-1-18.

22. Біловодська О. А. Формування і реалізація інвестиційних стратегій інноваційного розвитку підприємств: сутність, основні складові та оцінка. Бізнес Інформ. 2016. № 11. С. 204-210.

23. Gryshchenko I., Chubukova O., Bilovodska O., Gryshchenko O., Melnyk Yu. Marketing-oriented Approach to Evaluating the Strategy of Distribution Management for Innovative Products in Logistics. WSEAS Transactions on Environment and Development. 2020. Vol. 16. Art. \# 37. P. 371-383. https://doi.org/10.37394/232015.2020.16.37.

24. Офіційний сайт ПАТ “Сумихімпром”. URL : http://sumykhimprom.com.ua/ua/company/ (дата звернення 05.03.2021)

\section{References}

1. Amico S. Definition of Sales Strategy. Retrieved from https://smallbusiness.chron.com/definition-salesstrategy-2213.html [in English].

2. Zolters S. Analysing and Improving the Sales Strategy and Process Case: Robert Bosch Oy. Retrieved from https://www.theseus.fi/bitstream/handle/10024/129374/Kuosa_Samuel.pdf?sequence=1 [in English].

3. Official website of HubSpot, Inc. Retrieved from https://www.hubspot.com/sales/sales-strategy [in English].

4. Storbacka, K., Ryals, L., Davies, I., Nenonen, S. (2009). The changing role of sales: viewing sales as a strategic, cross-functional process. European Journal of Marketing, Vol. 43, No. 7/8, pp. 890-906. Retrieved from https://core.ac.uk/download/pdf/140054.pdf [in English].

5. Illiashenko, S. (2010). Stratehichne upravlinnia innovatsiinoiu diialnistiu pidpryiemstva na osnovi marketynhu innovatsii [Strategic management of enterprise innovative activity basing on marketing of innovations]. Actual Problems of Economics, 12, 2010, pp. 111-119 [in Ukrainian].

6. Babenko, V.A. (2013). Formirovaniie ekonomiko-matematicheskoi modeli dinamiky protsessa upravleniia innovatsionnymi tekhnolohiiami na predpriiatiiakh APK [Formation of economic-mathematical model for process dynamics of innovative technologies management at agroindustrial enterprises]. Actual Problems of Economics, 1 (139), pp. 182-186 [in Russian].

7. Babenko, V. (2019). Formalization of the Model of Management of the Technological Innovations. CEUR 
Workshop Proceedings, 2393, pp. 595-602. Retrieved from http://ceur-ws.org/Vol-2393/paper_431.pdf [in English].

8. Babenko, V., Romanenkov, Yu., Yakymova, L., Nakisko, A. (2017). Development of the model of minimax adaptive management of innovative processes at an enterprise with consideration of risks. Eastern-European Journal of Enterprise Technologies, Vol. 5, No. 4 (89), pp. 49-56. Retrieved from https://doi.org/10.15587/17294061.2017.112076 [in English].

9. Pererva, P., Besprozvannykh, O., Tiutlikova, V., Kovalova, V., Kudina, O., Dorokhov, O. (2019). Improvement of the Method for Selecting Innovation Projects on the Platform of Innovative Supermarket. TEM Journal, 8 (2), pp. 454-461. https://doi.org/10.18421/TEM82-19 [in English].

10. Huang, S., Jiang. H. (2018). Multimodal estimation of distribution algorithm based on cooperative clustering strategy. Chinese Control And Decision Conference (CCDC), 5297-5302. Retrieved from https://ieeexplore.ieee.org/document/8408052. doi: 10.1109/CCDC.2018.8408052 [in English].

11. Wang, L., Fan, H., Gong, T. (2018). The Consumer Demand Estimating and Purchasing Strategies Optimizing of FMCG Retailers Based on Geographic Methods. Sustainability, 10. Retrieved from https://doi.org/10.3390/su10020466 [in English].

12. Kurbatska, L., Ilchenko, T., Kadyrus, I. (2016). Teoretychni aspekty marketynhovoho zabezpechennia efektyvnoi rozpodilcho-zbutovoi polityky ahrarnoho pidpryiemstva [Theoretical aspects of marketing support for an effective distribution policy in an agricultural enterprise]. Scientific bulletin of Kherson State University, 21 (1), pp. $122-126$ Retrieved

from https://dspace.dsau.dp.ua/jspui/bitstream/123456789/240/1/\%d0\%a1\%d1\%82\%d0\%b0\%d1\%82\%d1\%82\%d1\%8f_\%d 0\%9a\%d1\%83\%d1\%80\%d0\%b1\%d0\%b0\%d1\%86\%d1\%8c\%d0\%ba\%d0\%b0\%2c\%20\%d0\%86\%d0\%bb\%d1\%8c\%d1 $\% 87 \%$ d0\%b5\%d0\%bd\%d0\%ba\%d0\%be\%2c\%20\%d0\%9a\%d0\%b0\%d0\%b4\%d0\%b8\%d1\%80\%d1\%83\%d1\%81.pdf [in Ukrainian].

13. Polishchuk, I. (2015). Otsinka efektyvnosti marketynhovoi stratehii pidpryiemstva [Evaluation of effectiveness of enterprise marketing strategy]. Problems of theory and methodology of accounting, control and $\begin{array}{llllll}\text { analysis, } & 3 & \text { (33), } & \text { pp. 259-271. } & \text { Retrieved from }\end{array}$ http://eztuir.ztu.edu.ua/bitstream/handle/123456789/2582/24.pdf?sequence=1\&isAllowed=y [in Ukrainian].

14. Persaud, N., Woodhouse-Jackson, M., \& Scriven, M. (2016). Enhancing the Strategic Management Process Through the Use of Professional Evaluation Methods and the Logic of Evaluation. Journal of MultiDisciplinary Evaluation, $12 \quad$ (26), $1-11 . \quad$ Retrieved from https://www.academia.edu/23582472/Enhancing the_Strategic_Management_Process_Through the Use_of_Professio nal_Evaluation Methods and the Logic of Evaluation Otsinka efektyvnosti marketynhovoi stratehii pidpryiemstva [in English].

15. Rivera, B., Becker, P., Papa, F., Olsina, L. (2016). A Holistic Quality Evaluation, Selection and Improvement Approach driven by Multilevel Goals and Strategies. CLEI Electronic Journal, 19 (3). Retrieved from http://www.scielo.edu.uy/scielo.php?script=sci_arttext\&pid=S0717-50002016000300054 [in English].

16. Norton, S., Milat, A., Edwards, B., \& Giffin, M. (2016). Narrative review of strategies by organizations for building evaluation capacity. Evaluation and Program Planning, 58, 1-19. Retrieved from https://www.sciencedirect.com/science/article/pii/S0149718915300616 [in English].

17. Rintanen, J. (n.d.). Evaluation Strategies for Planning as Satisfiability. Retrieved from https://users.aalto.fi/ rintanj1/jussi/papers/Rintanen04ecai.pdf [in English].

18. Kara, N. (2016). Vydy stratehii ta otsiniuvannia vplyvu faktoriv zovnishnoho seredovyshcha na diialnist pidpryiemstva [Strategy kinds and estimation of external environment factors influence activity of enterprise]. Retrieved from http://ena.lp.edu.ua/bitstream/ntb/34889/1/16 97-102.pdf [in Ukrainian].

19. Savytska, N., Chmil, H., Hrabylnikova, O., Pushkina, O., Vakulich, M. (2019). Behavioral models for ensuring the security of functioning and organizational sustainability of the enterprise. Journal of Security and Sustainability, 9(1), 63-76. DOI: 10.9770/jssi.2019.9.1(6) [in English].

20. Seredynska, V., Zahorodna, O. (2016). Napriamy vdoskonalennia stratehichnoho upravlinnia na pidpryiemstvi [Ways of the strategic management improvement of a company]. Economy and Society, 3, $276-285$. Retrieved from http://www.economyandsociety.in.ua/journal/3_ukr/49.pdf [in Ukrainian].

21. Shorikov, A., Babenko, V. (2014). Optymyzatsyia harantyrovannoho rezultata v dynamycheskoi modely upravlenyia ynnovatsyonnыm protsessom na predpryiatyy [Optimization of assured result in dynamical model of management of innovation process in the enterprise of agricultural production complex]. Economy of Region, 1, 196202. DOI: 10.17059/2014-1-18 [in Russian].

22. Bilovodska, O. (2016). Formuvannia i realizatsiia investytsiinykh stratehii innovatsiinoho rozvytku pidpryiemstv: sutnist, osnovni skladovi ta otsinka [Formation and implementation of investment strategies for innovative development of enterprises: essence, main components and evaluation]. Business Inform, 11, $204-210$ [in Ukrainian].

23. Gryshchenko, I., Chubukova, O., Bilovodska, O., Gryshchenko, O., Melnyk, Yu. (2020). Marketingoriented Approach to Evaluating the Strategy of Distribution Management for Innovative Products in Logistics. WSEAS Transactions on Environment and Development, $16 \quad$ (37), 371-383. https://doi.org/10.37394/232015.2020.16.37 [in English].

24. Official site JSC «Sumykhimprom». (2020). Retrieved from http://sumykhimprom.com.ua/ua/company/ [in Ukrainian]. 